\title{
METHODS OF ALLOCATION OF TASK TEAMS TO THE PLANNED WORKS
}

\begin{abstract}
T. KASPROWICZ ${ }^{1}$
ABSTRACT: Small construction objects are often built by standard task teams. The problem is, how to allocate these teams to individual works? To solve the problem of allocation three methods have been developed. The first method allows to designate optimal allocation of teams to the individual works in deterministic conditions of implementation. As a criterion of the optimal allocation can be applied: "the minimization of time" or "the minimization of costs" of works execution. The second method has been developed analogously for both criteria but for stochastic conditions and for the stochastic data. The third method allows to appoint a compromise allocation of teams. In this case, the criteria "the minimization of time" and "the minimization of costs" are considered simultaneously. The method can be applied in deterministic or stochastic conditions of works implementation. The solutions of the allocation problems which have been described allow to designate the optimal allocation of task teams and to determine the schedule and cost of works execution.
\end{abstract}

Keywords: task team, deterministic conditions, stochastic conditions, allocation, scheduling

\section{INTRODUCTION}

Small construction objects are often built using standard technology. In such cases construction works can be executed by standard task teams. It means that construction works can be executed in replicable way by task teams using the routine, typical building technique. Such efficient task teams can be picked from the constant set of executors or directly designed for the implementation of the planned works. In both cases, when there is more than one team to some works execution, there is a problem how to allocate these teams to individual works? In order to solve the problem three methods have been developed. For each method, the standardized procedures of task teams allocation have been developed. The procedure consists of three basic steps: designing optimal task

1 Prof. DSc., PhD., Eng., Military University of Technology, Faculty of Civil Engineering and Geodesy, 2 Gen, Witolda Urbanowicza Str., 00 - 908 Warsaw, Poland, e-mail: tadeusz.kasprowicz@wat.edu.pl 
teams, formulating of the teams allocation problem, solution of the task teams allocation problem. The main objective of the task team designing is to determine its optimal (rational) structure and equipment for the implementation of particular type of works [1, 2, 3]. Of course the bill of quantities of the planned works that have to be executed by task teams should be identified. The formulation of the task teams allocation problem describes existed execution restriction generated by set of teams and implementation conditions, and criterion or criteria of solution assessment. The solution of the formulation determines the best variant (according to the criterion of criteria) of the works execution. The solutions received with each method depend on defined criteria and execution restriction. The selection criteria can be used as follows:

- minimization of the final deadline of works completion - "minimization of time works";

- minimization of the total cost of works completion - "minimization of cost works";

- minimization of final deadline of works completion and minimization of total cost of works completion considered simultaneously - "compromise solution".

The proposed formulation of the problem and assessment criteria have to be described in detail according to the rules of particular method.

\section{RULES OF CONSTRUCTION TASK AND RESOURCES DESCRIPTION}

Construction tasks are executed according to the kind and structure of works and available resources [4]. Requirements of construction task conditions are described by using the design characteristics model of task structure $S$ as follows $[5,6]$ :

$$
\boldsymbol{S}=\langle\boldsymbol{G}, \boldsymbol{L}\rangle
$$

where:

$\boldsymbol{G}=\langle\boldsymbol{Y}, \boldsymbol{U}, \boldsymbol{P}\rangle-$ coherent and a-cyclic unigraph with a single initial node and a single final node that describes interdependence and permissible sequences of works execution,

$\boldsymbol{Y}=\left\{y_{1}, \ldots, y_{i}, \ldots, y_{k}, \ldots, y_{m}\right\}-$ set of the nodes of the graph representing initial and final events for each work $u_{j} \in \boldsymbol{U}$; the nodes mean: $y_{i}$ initial and $y_{k}$ final node of the work $u_{j}$ execution;

$\boldsymbol{U}=\left\{u_{1}, \ldots, u_{j}, \ldots, u_{l}, \ldots, u_{n}\right\}-$ set of the arcs (arrows) of the graph representing relatively independent works (activities) that are constrained by initial $y_{i} \in \boldsymbol{Y}$ and final $y_{k} \in \boldsymbol{Y}$ nodes;

$\boldsymbol{P} \subset \boldsymbol{Y} \times \boldsymbol{U} \times \boldsymbol{Y},\left\langle y_{i}, u_{j}, y_{k}\right\rangle \in \boldsymbol{P}$ - three-term relation that assigns to each arc $u_{j} \in \boldsymbol{U}$ the initial node $y_{i} \in \boldsymbol{Y}$ and final node $y_{k} \in \boldsymbol{Y}$;

$\boldsymbol{L}: \boldsymbol{U} \rightarrow \boldsymbol{R}^{+}$- function defined on the set $\boldsymbol{U}$ of arcs of the graph $\boldsymbol{G}$ that describes bill of quantities:

- $\quad$ in deterministic conditions: the number $l_{j}$ units of works $u_{j} \in \boldsymbol{U}$ scope (bill of quantities); 
- $\quad$ in stochastic conditions: the most probable number $\widehat{L}_{j} \in \boldsymbol{L}$ units of works $u_{j} \in U$ for $\left\langle y_{i}, u_{j}, y_{k}\right\rangle \in \boldsymbol{P}$.

The scope $l_{j}$ and $\hat{L}_{j} \in \boldsymbol{L}$ of works $u_{j} \in \boldsymbol{U}$ is calculated on the basis of construction design in which the planned works have been designed in detail. According to the design characteristics model of task structure $S$ the works execution are described by using the construction technology model $£$ $[5,6]$ :

$$
\mathcal{L}=\{\langle\boldsymbol{H}, \boldsymbol{K}, \boldsymbol{T}\rangle, \boldsymbol{S}\}
$$

where:

$\boldsymbol{H}=\left\{H^{1}, H^{2}, \ldots, H^{r}, \ldots, H^{S}\right\}, H^{r}=\left\{1,2, \ldots, h, \ldots h^{r}\right\}$ - set of rational or optimal task teams $H^{r}$ for works $u_{j} \in \boldsymbol{U}^{r}$ execution, $h$ - rudimentary resources (staff, laborers, tools, machines and the like), $\boldsymbol{T}:(\boldsymbol{H} \times \boldsymbol{U}) \rightarrow \boldsymbol{R}^{+}-$function defined on the set $\boldsymbol{H}$ of teams $H^{r}$ which determines:

- $\quad$ in deterministic conditions: the duration $t_{j, r}$ of works $u_{j} \in \boldsymbol{U}^{r} \subset \boldsymbol{U}$ when they are executed by team $H^{r}$;

- $\quad$ in stochastic conditions: the most probable duration $\widehat{T}_{j, r}$ of works $u_{j} \in \boldsymbol{U}^{r} \subset \boldsymbol{U}$ when they are executed by task team $H^{r}$;

$\boldsymbol{K}:(\boldsymbol{H} \times \boldsymbol{U}) \rightarrow \boldsymbol{R}^{+}-$function defined on the set $\boldsymbol{H}$ of task teams $H^{r}$ which determines:

- $\quad$ in deterministic conditions: the cost $k_{j, r}$ of works $u_{j} \in \boldsymbol{U}^{r} \subset \boldsymbol{U}$ when they are executed by task team $H^{r}$;

- $\quad$ in stochastic conditions: the most probable cost of works $u_{j} \in \boldsymbol{U}^{r} \subset \boldsymbol{U}$ when they are executed by task team $H^{r}$.

The duration $t_{j, r}$ can be calculated by using the formula $t_{j, r}=l_{j} p_{j, r}$. The duration $\widehat{T}_{j, r}$ by using the formula $\widehat{T}_{j, r}=\widehat{L}_{j} \hat{P}_{j, r}$ or based on the individual calculation [6]. Quantities $t_{j, r}$ and $\widehat{T}_{j, r}$ can be also determined directly based on individual calculations The cost $k_{j, r}$ and $\widehat{K}_{j, r}$ can be calculated as follows $k_{j, r}=t_{j, r} c_{j, r}^{t}$ or $k_{j, r}=l_{j, r} c_{j, r}^{l}$ and $\widehat{K}_{j, r}=\widehat{T}_{j, r} \hat{C}_{j, r}^{t}$ or $\widehat{K}_{j, r}=\widehat{L}_{j, r} \hat{C}_{j, r}^{l}$. Quantities $k_{j, r}$ and $\widehat{K}_{j, r}$ can also be determined directly based on individual estimations. The realistic number $p_{j, r}$ of time units which are necessary for the execution of each unit of works $u_{j} \in \boldsymbol{U}^{r} \subset \boldsymbol{U}$ by the team $H^{r} \in \boldsymbol{H}$ can be determined on the basis of commonly used catalogs of standards of resource consumption or directly based on individual estimation [6]. The unit $\operatorname{cost} c_{j, r}^{t}$ and $\hat{C}_{j, r}^{t}$ (e.g. dollars per working hour) or $c_{j, r}^{l}$ and $\hat{C}_{j, r}^{l}$ (e.g. dollars per cubic meter) which must be spent on the execution of the works $u_{j} \in \boldsymbol{U}^{r} \subset \boldsymbol{U}$ by team $H^{r}$ can be estimated by using the commonly used price lists or directly based on individual estimation. The described models constitute all restrictions of works execution. Based on them it is possible to formulate the problems of allocation of task teams to the works execution. 


\section{AlLOCATION OF TASK TEAMS TO THE PLANNED WORKS}

\subsection{ALLOCATION OF TASK TEAMS TO THE PLANNED WORKS IN DETERMINISTIC CONDITIONS}

Deterministic conditions of works implementation can be assumed, when random events do not interfere with the works execution and task teams can perform works without significant disturbances. Moreover, the system and natural environment of works execution can be considered as very stable. In such cases, all restrictions of works execution can be described by using the design characteristics model of a task structure $\boldsymbol{S}=\langle\boldsymbol{G}, \boldsymbol{L}\rangle$ and the construction technology model $\mathscr{L}=\{\langle\boldsymbol{H}, \boldsymbol{K}, \boldsymbol{T}\rangle, \boldsymbol{S}\}$ in compliance with rules described above. Based on the models the allocation problem can be formulated as follows:

- calculate the earliest final deadline $v_{m}$ of works $S$ completion by using resources $£$, and the early start $v_{i}$, that is calculate the values of the variables $\left\langle v_{1}, \ldots, v_{i}, \ldots, v_{m}\right\rangle$ that minimize the function $t$ :

$$
t=\sum_{i=1}^{m} v_{i} \rightarrow \min
$$

under the constraints:

$$
\begin{aligned}
& v_{k}-v_{i} \geq \sum_{H^{j_{\in} \boldsymbol{H}^{r}}} t_{j, r} x_{j, r} \text { for } u_{j} \in U, j=1,2, \ldots, n_{i} ;\left\langle y_{i}, u_{j}, y_{k}\right\rangle \in \boldsymbol{P} \\
& v_{i}-v_{e} \geq \sum_{u_{f \in U^{r}}} t_{f, r} x_{f, r}-B\left(1-x_{i, e}\right)-G\left(1-x_{j, r}\right) \\
& v_{e}-v_{i} \geq \sum_{u_{j} \in U^{r}} t_{j, r} x_{j, r}-B x_{i, e}-G x_{f, r} \\
& \sum_{H^{r} \in \boldsymbol{H}_{j}} x_{j, r}=1 \text { for } u_{j} \in \boldsymbol{U}, j=1,2, \ldots, n \\
& \begin{array}{c}
\text { for } H^{r} \in \boldsymbol{H}^{s} \text { when } \\
H^{r} \in \boldsymbol{H}_{j} \cap \boldsymbol{H}_{f}, u_{j} \| u_{f}, y_{i} \neq y_{e} \\
\left.y_{i}, u_{j}, y_{k}\right\rangle \in \boldsymbol{P},\left\langle y_{e}, u_{f}, y_{g}\right\rangle \in \boldsymbol{P}_{i}
\end{array}
\end{aligned}
$$


where:

$v_{i}, v_{e} \geq 0$ for $i=1,2, \ldots, m$

$x_{j, r}=\left\{\begin{array}{l}1, \text { when the work } u_{j} \in \boldsymbol{U} \text { is executed by task team } H^{r} \in \boldsymbol{H}_{j} \\ 0, \text { in opposite case }\end{array}\right.$

$x_{f, r}=\left\{\begin{array}{l}1, \text { when the work } u_{j} \in \boldsymbol{U} \text { is executed by task team } H^{f} \in \boldsymbol{H}_{j} \\ 0, \text { in opposite case }\end{array}\right.$

$x_{i, e}=\left\{\begin{array}{l}1, \text { when } v_{i} \geq v_{e} \\ 0, \text { in opposite case }\end{array}\right.$

- calculate the earliest final deadline $v_{m}$ of works $\boldsymbol{S}$ completion by using resources $\mathscr{£}$ and the late start $v_{i}$, that is calculate the values of the variables $\left\langle v_{1}, \mathrm{~K}, v_{i}, \mathrm{~K}, v_{m}\right\rangle$ that maximize the function $t$ :

$t=\sum_{i=1}^{m} v_{i} \rightarrow \max$

under the constraints:

$$
\left.\begin{array}{l}
v_{k}-v_{i} \geq \sum_{H^{j} \in \boldsymbol{H}^{r}} t_{j, r} x_{j, r} \text { for } u_{j} \in U, j=1,2, \ldots, n_{i} ;\left\langle y_{i}, u_{j}, y_{k}\right\rangle \in \boldsymbol{P} \\
v_{i}-v_{e} \geq \sum_{u_{f \in U^{r}}} t_{f, r} x_{f, r}-B\left(1-x_{i, e}\right)-G\left(1-x_{j, r}\right) \\
v_{e}-v_{i} \geq \sum_{u_{j} \in U^{r}} t_{j, r} x_{j, r}-B x_{i, e}-G x_{f, r} \\
\sum_{H^{r} \in \boldsymbol{H}_{j}} x_{j, r}=1 \text { for } u_{j} \in \boldsymbol{U}, j=1,2, \ldots, n \\
v_{m} \leq \min v_{m}
\end{array}\right\} \begin{gathered}
\text { for } H^{r} \in \boldsymbol{H}^{S} \text { when } \\
H^{r} \in \boldsymbol{H}_{j} \cap \boldsymbol{H}_{f}, u_{j} \| u_{f}, y_{i} \neq y_{e} \\
\left\langle y_{i}, u_{j}, y_{k}\right\rangle \in \boldsymbol{P},\left\langle y_{e}, u_{f}, y_{g}\right\rangle \in \boldsymbol{P}_{i}
\end{gathered}
$$

where:

$v_{i}, v_{e}, x_{j, r}, x_{f, r}, x_{i, e}-$ as above.

The best allocation of task teams to the planned works $(3.1,3.2)$ has been settled here according to the criterion "minimization of the final deadline of works completion". In many cases more interesting may be solution of the problem on the ground of cost. In such case, general restrictions can be the same as for calculation the earliest final deadline $v_{m}$ of works $\boldsymbol{S}$ completion by using 
resources $£$ and the early start $v_{i}$ but the criterion of the solution designation should be "minimization of the total cost of works completion" as follows:

$$
k=\sum_{j=1}^{n} \sum_{H^{r} \in H_{j}} c_{j, r} x_{j, r} \rightarrow \min
$$

It is clear that the solution obtained with the criterion of time and the solution designated with the criterion of cost are usually different. The solution of the both allocation problems one can designate by using any standard computer program. The solution sets optimal allocation of the task teams to the execution of planned works in deterministic conditions under the time or cost criteria.

\subsection{ALLOCATION OF THE TASK TEAMS TO THE PLANNED WORKS IN STOCHASTIC CONDITIONS}

Stochastic conditions of works implementation should be assumed when intrinsic random events can strongly interfere with the execution of works and powerfully disturb the action of the task teams $[8,9]$. Of course, the execution and activity of task teams can be disturbed by the external random events that can be generated by the system and natural environment of works execution. In such situation, all restrictions of works execution can be described by using the design characteristics model of a task structure $\boldsymbol{S}=\langle\boldsymbol{G}, \boldsymbol{L}\rangle$ and the construction technology model $\mathfrak{E}=\{\langle\boldsymbol{H}, \boldsymbol{K}, \boldsymbol{T}\rangle, \boldsymbol{S}\}$ in compliance with rules described above (point 2). But now, for the formulation of allocation problem it is necessary calculation of expected values of the duration $E\left[T_{j, r}\right]$ and the cost $E\left[K_{j, r}\right]$ of the works $u_{j} \in \boldsymbol{U}$ execution by teams $H^{r} \in \boldsymbol{H}^{S}$ as follow [10]:

$$
E\left[T_{j, r}\right]=\frac{T_{j, r}+\widehat{T}_{j, t}+\bar{T}_{j, r}}{6} \text { and } E\left[K_{r, j}\right]=\frac{K_{r, j}+\widehat{K}_{r, j}+\bar{K}_{r, j}}{6} ;
$$

The values $\widehat{T}_{j, r}$ and $\widehat{K}_{j, r}$ can be calculated by using the formulas presented in the point 2 of the paper. The values $\underline{T}_{j, r}, \underline{K}_{j, r}, \bar{T}_{j, r}$ and $\bar{K}_{j, r}$ should be calculated depending on the possible influences of random events on the run and results of works execution. It can be done using the formulas [4, 5]:

- $\quad$ the optimistic values of duration $\underline{T}_{j, r}$ and costs $\underline{K}_{j, r}$ :

$$
\underline{T}_{j, r}=\widehat{T}_{j, r}-\underline{p}_{j, r}^{t} \widehat{T}_{j, r} \text { and } \underline{K}_{j, r}=\widehat{K}_{j, r}-\underline{p}_{j, r}^{k} \widehat{K}_{j, r} ;
$$


- the pessimistic values of duration $\bar{T}_{j, r}$ and costs $\bar{K}_{j, r}$ :

$$
\bar{T}_{j, r}=\widehat{T}_{j, r}+\bar{p}_{j, r}^{t} \widehat{T}_{j, r} \text { and } \bar{K}_{j, r}=\widehat{K}_{j, r}+\bar{p}_{j, r}^{k} \widehat{K}_{j, r} ;
$$

The coefficients of optimism $\underline{p}_{j, r}^{t}$ describe the possible shortening of works duration in stochastic conditions because of possible better implementation conditions and the likely weakening of the random events impact on the course and results of the works. The coefficients of pessimism $\bar{p}_{j, r}^{t}$ describe the possible lengthening of project duration in stochastic conditions because of possible worse implementation conditions and the likely strengthening of the random events impact on the course and results of the work. Similarly, because of possible better or worse implementation conditions the coefficients of optimism $\underline{p}_{j, r}^{k}$ or the coefficients of pessimism $\bar{p}_{j, r}^{k}$ can be determined. The best allocation of task teams to the planned works can be scheduled similarly as in deterministic conditions (point 3.1), in accordance with formulas 3.1, 3.2 and 3.3 but for stochastic data.

\subsection{COMPROMISE ALLOCATION OF TASK TEAMS TO THE PLANNED WORKS}

The compromise allocation of task teams to the planned works has been scheduled according to the two criteria considered simultaneously: "minimization of duration $t$ " and "minimization of cost $k$ " of works execution as follow:

$$
t=\sum_{i=1}^{m} v_{i} \rightarrow \min \text { and } k=\sum_{j=1}^{n} \sum_{H^{r} \in \boldsymbol{H}_{j}} c_{j, r} x_{j, r} \rightarrow \min
$$

These criteria are contradictory. The compromise solution in deterministic and stochastic implementation conditions can be designated as a solution of the similar problem but for appropriate (deterministic or stochastic) data. The allocation problem has been formulated as follow $[11,12]$ :

- calculate the earliest final deadline $v_{m}$ of works $\boldsymbol{S}$ completion by using resources $£$ and the early start $v_{i}$, that is calculate the values of the variables $\left\langle v_{1}, \mathrm{~K}, v_{i}, \mathrm{~K}, v_{m}\right\rangle$ that minimize the functions $t k$ :

$$
t k=x^{t} x^{k} \rightarrow \min
$$


under the constraints:

$$
\begin{aligned}
& \sum_{i=1}^{m} v_{i}-\min t x^{t} \leq \min t \\
& \sum_{j=1}^{n} \sum_{H^{r} \in \boldsymbol{H}_{j}} c_{j, r} x_{j, r}-\min k x^{k} \leq \min k \\
& v_{k}-v_{i} \geq \sum_{H^{j} \in \boldsymbol{H}^{r}} t_{j, r} x_{j, r} \text { for } u_{j} \in U, j=1,2, \ldots, n_{i} ;\left\langle y_{i}, u_{j}, y_{k}\right\rangle \in \boldsymbol{P} \\
& v_{i}-v_{e} \geq \sum_{u_{f \in U^{r}}} t_{f, r} x_{f, r}-B\left(1-x_{i, e}\right)-G\left(1-x_{j, r}\right) \quad \begin{array}{r}
\text { for } H^{r} \in \boldsymbol{H}^{S} \text { when } \\
H^{r} \in \boldsymbol{H}_{j} \cap \boldsymbol{H}_{f}, u_{j} \| u_{f,} y_{i} \neq u^{\prime}
\end{array} \\
& v_{e}-v_{i} \geq \sum_{u_{j} \in U^{r}} t_{j, r} x_{j, r}-B x_{i, e}-G x_{f, r} \quad\left\{\begin{array}{c}
H^{r} \in \boldsymbol{H}_{j} \cap \boldsymbol{H}_{f}, u_{j} \| u_{f}, y_{i} \neq y_{e} \\
\left\langle y_{i}, u_{j}, y_{k}\right\rangle \in \boldsymbol{P},\left\langle y_{e}, u_{f}, y_{g}\right\rangle \in \boldsymbol{P}_{i}
\end{array}\right. \\
& \sum_{H^{r} \in \boldsymbol{H}_{j}} x_{j, r}=1 \text { for } u_{j} \in \boldsymbol{U}, j=1,2, \ldots, n
\end{aligned}
$$

where:

$v_{i}, v_{e}, x_{j, r}, x_{f, r}, x_{i, e}-$ as above.

The solution of the allocation problem describes compromise assignment teams to the planned works. It is the best allocation according to the two criteria considered simultaneously

\section{EXPLANATION EXAMPLE}

Allocation of the task teams to the planned works of the small bridge construction can be designated by using described methods. The bridge can be reared up in the deterministic or stochastic conditions. In both situations the bridge model and construction task list has been presented on fig. 2. The construction technology of the bridge has been presented on fig. 2 .

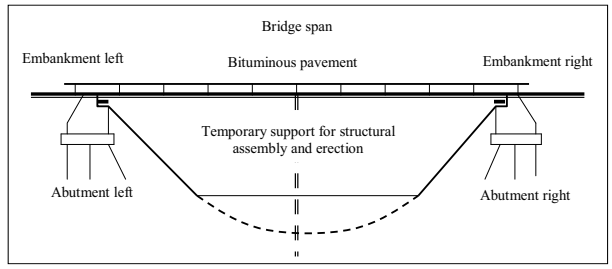

Fig. 1. Bridge model and construction task list

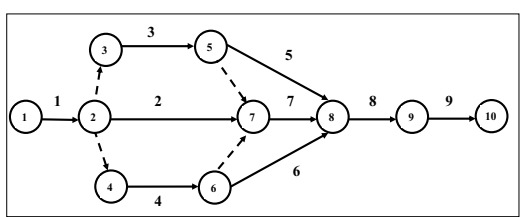

Fig. 2. Graph of the bridge construction technology 
The computational data for the deterministic conditions which described the bridge construction according to the models $\boldsymbol{S}$ and $\mathcal{L}$ have been presented in the table 1 .

Table 1. Data for the design characteristics model of the bridge structure $\boldsymbol{S}$ and the bridge construction technology model $\mathfrak{L}$-deterministic conditions

\begin{tabular}{|c|c|c|c|c|c|c|c|c|c|}
\hline No. & Title & $u_{j}$ & $y_{i}$ & $y_{k}$ & $v_{i}$ & $v_{k}$ & $H^{r}$ & $\begin{array}{c}\text { Duration } \\
\text { (days) } \\
t_{j}\end{array}$ & $\begin{array}{c}\text { Cost } \\
(\mathrm{PLN}) \\
k_{j}\end{array}$ \\
\hline 1 & 2 & 3 & 4 & 5 & 6 & 7 & 8 & 9 & 10 \\
\hline 1 & $\begin{array}{l}\text { Land development and } \\
\text { preconstruction works }\end{array}$ & 1 & 1 & 2 & $v_{1}$ & $v_{2}$ & 1 & 43 & 58080 \\
\hline 2 & $\begin{array}{l}\text { Temporary support for structural } \\
\text { assembly and erection }\end{array}$ & 2 & 2 & 7 & $v_{2}$ & $v_{7}$ & 2 & 45 & 39072 \\
\hline 3 & Abutment left & 3 & 3 & 5 & $v_{3}$ & $v_{5}$ & 3 & 187 & 3806851 \\
\hline 4 & & & & & & & 4 & 150 & 4524175 \\
\hline 5 & & & & & & & 5 & 165 & 4203684 \\
\hline 6 & Abutment lright & 4 & 4 & 6 & $v_{4}$ & $v_{6}$ & 3 & 147 & 2702322 \\
\hline 7 & & & & & & & 4 & 114 & 2293666 \\
\hline 8 & & & & & & & 5 & 139 & 2796663 \\
\hline 9 & Bridge span & 7 & 7 & 8 & $v_{7}$ & $v_{8}$ & 6 & 222 & 5928098 \\
\hline 10 & Embankment left & 5 & 5 & 8 & $v_{5}$ & $v_{8}$ & 7 & 71 & 7060 \\
\hline 11 & & & & & & & 8 & 55 & 5040 \\
\hline 12 & Embankment right & 6 & 6 & 8 & $v_{6}$ & $v_{8}$ & 7 & 90 & 10020 \\
\hline 13 & & & & & & & 8 & 80 & 8270 \\
\hline 14 & Bituminous pavement & 8 & 8 & 9 & $v_{8}$ & $v_{9}$ & 9 & 13 & 20166 \\
\hline 15 & Finishing works & 9 & 9 & 10 & $v_{9}$ & $v_{10}$ & 10 & 48 & 48063 \\
\hline
\end{tabular}

The solution of the allocation problem has been developed according to the rules and formulas 3.1, 3.2, 3.3. The results of the calculation has been presented in table 2 . 
Table 2. The results of the problems allocation solution - deterministic conditions

\begin{tabular}{|c|c|c|c|c|c|c|c|}
\hline \multicolumn{4}{|c|}{ Minimization of duration } & \multicolumn{2}{|c|}{ Minimization of cost } & \multicolumn{2}{|c|}{ Compromise solution } \\
\hline Allocation & Early start & Allocation & Last start & Allocation & Early start & Allocation & Early start \\
\hline 1 & 2 & & 3 & 4 & 5 & 6 & 7 \\
\hline 1 & 0 & 1 & 0 & 1 & 0 & 1 & 0 \\
\hline 1 & 43 & 1 & 43 & 1 & 43 & 1 & 43 \\
\hline 0 & \multirow{3}{*}{43} & 0 & \multirow{3}{*}{43} & 1 & \multirow{3}{*}{43} & 0 & \multirow{3}{*}{43} \\
\hline 1 & & 1 & & 0 & & 0 & \\
\hline 0 & & 0 & & 0 & & 1 & \\
\hline 0 & \multirow{3}{*}{43} & 0 & \multirow{3}{*}{54} & 0 & \multirow{3}{*}{43} & 0 & \multirow{3}{*}{43} \\
\hline 0 & & 0 & & 1 & & 1 & \\
\hline 1 & & 1 & & 0 & & 0 & \\
\hline 1 & 193 & 1 & 193 & 1 & 285 & 1 & 208 \\
\hline 1 & \multirow{2}{*}{193} & 1 & \multirow{2}{*}{193} & 0 & \multirow{2}{*}{230} & 1 & \multirow{2}{*}{208} \\
\hline 0 & & 0 & & 1 & & 0 & \\
\hline 0 & \multirow{2}{*}{182} & 0 & \multirow{2}{*}{193} & 0 & \multirow{2}{*}{285} & 0 & \multirow{2}{*}{208} \\
\hline 1 & & 1 & & 1 & & 1 & \\
\hline 1 & 415 & 1 & 415 & 1 & 507 & 1 & 430 \\
\hline 1 & 428 & 1 & 428 & 1 & 520 & 1 & 443 \\
\hline $\begin{array}{r}\text { Minimum } \\
\text { duration } \\
(\text { days }) \\
\end{array}$ & 476 & $\begin{array}{r}\text { Minimum } \\
\text { duration } \\
\text { (days) } \\
\end{array}$ & 476 & $\begin{array}{r}\text { Duration } \\
\text { (days) }\end{array}$ & 568 & $\begin{array}{r}\text { Compromise } \\
\text { duration } \\
(\text { days }) \\
\end{array}$ & 491 \\
\hline Cost (PLN) & 13429648 & Cost (PLN) & 13429647 & $\begin{array}{c}\text { Minimum } \\
\text { cost (PLN) }\end{array}$ & 12207306 & $\begin{array}{r}\text { Compromise } \\
\text { cost (PLN) }\end{array}$ & 12606159 \\
\hline
\end{tabular}

The computational data for the stochastic conditions which described the bridge construction according to the models $\boldsymbol{S}$ and $\mathscr{E}$ have been presented in the table 3 .

Table 3. Basic data for the design characteristics model of the bridge structure $\boldsymbol{S}$ and the bridge construction technology model $\mathfrak{L}$ - stochastic conditions

\begin{tabular}{|c|c|c|c|c|c|c|c|c|c|c|c|c|c|c|c|}
\hline \multirow[b]{2}{*}{ No. } & \multirow[b]{2}{*}{ Title } & \multirow[b]{2}{*}{$\mathrm{u}_{j}$} & \multirow[b]{2}{*}{$\mathrm{y}_{i}$} & \multirow[b]{2}{*}{$\mathrm{y}_{k}$} & \multirow[b]{2}{*}{$\mathrm{v}_{i}$} & \multirow[b]{2}{*}{$\mathrm{v}_{k}$} & \multirow[b]{2}{*}{$\mathrm{H}^{r}$} & \multicolumn{4}{|c|}{ Duration (days) } & \multicolumn{4}{|c|}{ Cost (PLN) } \\
\hline & & & & & & & & $E\left[T_{j}\right]$ & $\underline{T}_{j}$ & $\hat{T}_{j}$ & $\bar{T}_{j}$ & $E\left[K_{j}\right]$ & $\underline{K}_{j}$ & $\widehat{K}_{j}$ & $\bar{K}_{j}$ \\
\hline \begin{tabular}{|l|}
1 \\
\end{tabular} & 2 & 3 & 4 & 5 & 6 & 7 & 8 & 9 & 10 & 11 & 12 & 13 & 14 & 15 & 16 \\
\hline 1 & $\begin{array}{l}\text { Land development and } \\
\text { preconstruction works }\end{array}$ & 1 & 1 & 2 & $v_{1}$ & $v_{2}$ & 1 & 44 & 37 & 43 & 54 & 59048 & 49368 & 58080 & 72600 \\
\hline 2 & $\begin{array}{l}\text { Temporary support for structural } \\
\text { assembly and erection }\end{array}$ & 2 & 2 & 7 & $v_{2}$ & $v_{7}$ & 2 & 46 & 38 & 45 & 56 & 39723 & 33211 & 39072 & 48840 \\
\hline 3 & Abutment left & 3 & 3 & 5 & $v_{3}$ & $v_{5}$ & 3 & 190 & 159 & 187 & 234 & 3870299 & 3235823 & 3806851 & 4758564 \\
\hline \begin{tabular}{|l|}
4 \\
\end{tabular} & & & & & & & 4 & 153 & 128 & 150 & 188 & 4599578 & 3845549 & 4524175 & 5655219 \\
\hline \begin{tabular}{|l|}
5 \\
\end{tabular} & & & & & & & 5 & 168 & 140 & 165 & 206 & 4273745 & 3573131 & 4203684 & 5254605 \\
\hline 6 & Abutment lright & 4 & 4 & 6 & $v_{4}$ & $v_{6}$ & 3 & 149 & 125 & 147 & 184 & 2747361 & 2296974 & 2702322 & 3377903 \\
\hline \begin{tabular}{|l|}
7 \\
\end{tabular} & & & & & & & 4 & 116 & 97 & 114 & 143 & 2331894 & 1949616 & 2293666 & 2867083 \\
\hline \begin{tabular}{|l|}
8 \\
\end{tabular} & & & & & & & 5 & 141 & 118 & 139 & 174 & 2843274 & 2377163 & 2796663 & 3495829 \\
\hline \begin{tabular}{|l|}
9 \\
\end{tabular} & Bridge span & 7 & 7 & 8 & $v_{7}$ & $v_{8}$ & 6 & 226 & 189 & 222 & 278 & 6026900 & 5038883 & 5928098 & 7410123 \\
\hline 10 & Embankment left & 5 & 5 & 8 & $v_{5}$ & $v_{8}$ & 7 & 72 & 60 & 71 & 89 & 7178 & 6001 & 7060 & 8825 \\
\hline \begin{tabular}{|l|}
11 \\
\end{tabular} & & & & & & & 8 & 56 & 47 & 55 & 69 & 5124 & 4284 & 5040 & 6300 \\
\hline 12 & Embankment right & 6 & 6 & 8 & $v_{6}$ & $v_{8}$ & 7 & 92 & 77 & 90 & 113 & 10187 & 8517 & 10020 & 12525 \\
\hline 13 & & & & & & & 8 & 81 & 68 & 80 & 100 & 8408 & 7030 & 8270 & 10338 \\
\hline 14 & Bituminous pavement & 8 & 8 & 9 & $v_{8}$ & $v_{9}$ & 9 & 13 & 11 & 13 & 16 & 20502 & 17141 & 20166 & 25208 \\
\hline 15 & Finishing works & 9 & 9 & 10 & $v_{9}$ & $v_{10}$ & 10 & 49 & 41 & 48 & 60 & 48864 & 40854 & 48063 & 60079 \\
\hline
\end{tabular}


The solution of the allocation problem has been developed according to the rules and formulas 3.7, 3.10. The results of the calculation has been presented in table 4 .

Table 4. The results of the compromise solution of the allocation problems solution - stochastic conditions

\begin{tabular}{|c|c|c|c|c|c|c|c|}
\hline \multicolumn{4}{|c|}{ Minimization of duration } & \multicolumn{2}{|c|}{ Minimization of cost } & \multicolumn{2}{|c|}{ Compromise solution } \\
\hline Allocation & Early start & Allocation & Last start & Allocation & Early start & Allocation & Early start \\
\hline 1 & 2 & 3 & 4 & 5 & 6 & 7 & 8 \\
\hline 1 & 0 & 1 & 0 & 1 & 0 & 1 & 0 \\
\hline 1 & 44 & 1 & 44 & 1 & 44 & 1 & 44 \\
\hline 0 & \multirow{3}{*}{44} & 0 & \multirow{3}{*}{44} & 1 & \multirow{3}{*}{44} & 0 & \multirow{3}{*}{44} \\
\hline 1 & & 1 & & 0 & & 0 & \\
\hline 0 & & 0 & & 0 & & 1 & \\
\hline 0 & \multirow{3}{*}{44} & 0 & \multirow{3}{*}{44} & 0 & \multirow{3}{*}{44} & 0 & \multirow{3}{*}{44} \\
\hline 0 & & 0 & & 1 & & 1 & \\
\hline 1 & & 1 & & 0 & & 0 & \\
\hline 1 & 196 & 1 & 196 & 1 & 290 & 1 & 211 \\
\hline 1 & \multirow{2}{*}{196} & 1 & \multirow{2}{*}{196} & 0 & \multirow{2}{*}{234} & 1 & \multirow{2}{*}{211} \\
\hline 0 & & 0 & & 1 & & 0 & \\
\hline 0 & \multirow{2}{*}{185} & 0 & \multirow{2}{*}{196} & 0 & \multirow{2}{*}{290} & 0 & \multirow{2}{*}{211} \\
\hline 1 & & 1 & & 1 & & 1 & \\
\hline 1 & 422 & 1 & 422 & 1 & 515 & 1 & 437 \\
\hline 1 & 435 & 1 & 435 & 1 & 529 & 1 & 450 \\
\hline $\begin{array}{r}\text { Minimum } \\
\text { duration } \\
\text { (days) } \\
\end{array}$ & 484 & $\begin{array}{r}\text { Minimum } \\
\text { duration } \\
(\text { days }) \\
\end{array}$ & 484 & $\begin{array}{r}\text { Duration } \\
\text { (days) }\end{array}$ & 577 & $\begin{array}{r}\text { Compromise } \\
\text { duration } \\
\text { (days) }\end{array}$ & 499 \\
\hline Cost (PLN) & 13653474 & Cost (PLN) & 13653474 & $\begin{array}{r}\text { Minimum } \\
\text { cost (PLN) }\end{array}$ & 12410761 & $\begin{array}{r}\text { Compromise } \\
\text { cost (PLN) }\end{array}$ & 12816262 \\
\hline
\end{tabular}

The solutions of the allocation problems designate the optimal allocation of task teams to the planned works. Each solution determine duration and cost of works execution.

\section{Conclusions}

Methods of allocation of task teams to the planned works allow comprehensive analysis of the project execution on the construction site. Each method applies data which are used actually in practice. Comparison of the calculation results allows to confirm that the adoption of the computational model should be preceded by a rigorous analysis of the implementation conditions. This is closely linked with the proper selection of the objective function, which decides on the designation of task teams to the planned works and schedule the time and cost of the works completion. The methods have been developed for using during the planning of implementation of small construction projects. Each described method consists the formulation of the allocation problem that can be solved by using the similar computer program. It is possible to automate the problems formulation and solution based on data described which the construction contracts possess. 


\section{REFERENCES}

1. Kapliński O., red., Metody $i$ modele badań $w$ inżynierii przedsięwzięć budowlanych. Warszawa: PAN, KILiW, Instytut Podstawowych Problemów Techniki, 2007.

2. Kasprowicz T., red. Inżynieria przedsięwzięć budowlanych. Rekomendowane metody $i$ techniki. Warszawa: PAN, KILiW, Sekcja Inżynierii Przedsięwzięć budowlanych, 2015.

3. Sobotka A., Radziszewska-Zielina E., red., Inżynieria przedsięwzięć budowlanych. Problemy, modele, metody. Warszawa-Kraków: PAN, KILiW, 2018.

4. Czarnigowska, A., Sobotka, A. Time-cost relationship for predicting construction duration. Archives of Civil and Mechanical Engineering, 13(4) (2013), 518-526.

5. Kasprowicz T., Quantitative identification of construction risk, Archive of civil Engineering, Volume LXIII, Issue $1 / 2017,63-72$.

6. Kasprowicz T., Quantitative assessment of construction risk, Archive of civil Engineering, Volume LXIII, Issue 2/2017, 55-66.

7. Kasprowicz T., Quantitative estimation of the impact of random confounding factors for the duration and cost of construction works, Technical Transactions, Volume 8, Year 2017 (114), 73-79.

8. Skorupka, D., Kowacka, M. Identification of risk factors of development and operation of roads in the light of surveying work. Archives of Civil Engineering, Vol. 62(2) (2016), 183-190.

9. Połoński, M. Harmonogramowanie realizacji przedsięwzięć budowlanych z uwzględnieniem buforów czasu wyznaczonych na podstawie analizy ryzyka. Budownictwo i Architektura, 12(1) (2013), 47-52.

10. Hajdu M., Bokor O., Sensitivity analysis in PERT networks: Does activity duration distribution matter? Automation in Construction 65, 1-8, 2016.

11. Saul I. Gass, Pallabi Guha Roy,The compromise hypersphere for multiobjective linear programming, European Journal of Operational Research 144, 459-479, 2003.

12. Fouad Ben Abdelaziz, Hatem Masri, A compromise solution for the multiobjective stochastic linear programming under partial uncertainty, European Journal of Operational Research 202 (2010) 55-59 


\section{LIST OF FIGURES AND TABLES:}

Fig. 1. Bridge model and construction tasks list.

Rys. 1. Model mostu i lista robót budowlanych

Fig. 2. Graph of the bridge construction technology

Rys. 2. Graf technologii budowy mostu

Table 1. Data for the design characteristics model of the bridge structure $\boldsymbol{S}$ and the bridge construction technology model $\mathcal{L}$-deterministic conditions

Tablica 1. Dane modelu $\boldsymbol{S}$ technologii konstrukcji mostu i modelu $\mathfrak{L}$ technologii robot budowlanych warunki deterministyczne

Table 2. The results of the problems allocation solution - deterministic conditions

Tablica 2. Wyniki rozwiązania problemów przydziału - warunki deterministyczne

Table 3. Data for the design characteristics model of the bridge structure $S$ and the bridge construction technology model $\mathfrak{L}$ - stochastic conditions

Tablica 3. Dane modelu $\boldsymbol{S}$ technologii konstrukcji mostu i modelu $\mathfrak{L}$ technologii robot budowlanych warunki stochastyczne

Table 4. The results of the problems allocation solution - stochastic conditions

Tablica 4. Wyniki rozwiązania problemów przydziału - warunki stochastyczne 


\section{METODY PRZYDZIALU ZESPOŁÓW ZADANIOWYCH DO PLANOWANYCH ROBÓT}

Slowa kluczowe: zespół zadaniowy, warunki deterministyczne, warunki stochastyczne, przydział, harmonogramowanie

\section{STRESZCZENIE}

Małe obiekty budowlane są często budowane z zastosowaniem standardowych technologii. W takich przypadkach roboty budowlane mogą być wykonywane przez standardowe zespoły zadaniowe. W związku z tym konieczne jest określenie metod przydziału (alokacji) zespołów do wykonania poszczególnych robót. W celu rozwiązania tego problemu opracowano trzy metody przydziału, które mogą być zastosowane zarówno w deterministycznych jak i stochastycznych warunkach realizacji robót. Opracowane metody wykorzystują dane opisujące budowę. Dane dotyczące konstrukcji obiektu określane są na podstawie projektu budowlanego. Opracowywany jest model $\boldsymbol{S}=\langle\boldsymbol{G}, \boldsymbol{L}\rangle$ technologii konstrukcji obiektu. Model $S$ opisuje zarówno w warunkach deterministycznych jak i stochastycznych strukturę $\boldsymbol{G}$ przewidywanych robót budowlanych $u_{j} \in \boldsymbol{U} \subset \boldsymbol{G}$, czyli rodzaj i współzależność robót, oraz zbiór $\boldsymbol{L}$, który określa przedmiar robót $\mathrm{w}$ warunkach deterministycznych $l_{j} \in \boldsymbol{L}$ lub w warunkach stochastycznych $\hat{L}_{j} \in \boldsymbol{L}$.

Uwzględniając wymagania modelu technologii konstrukcji $\boldsymbol{S}$, na podstawie analizy warunków realizacji robót i posiadanych zasobów elementarnych $\{1,2, \ldots, h, \ldots\}$, opracowywany jest model $\mathfrak{L}=\{\langle\boldsymbol{H}, \boldsymbol{K}, \boldsymbol{T}\rangle, \boldsymbol{S}\}$ technologii robót budowlanych. Model $\mathfrak{L}$ opisuje zbiór $\boldsymbol{H}$ zespołów zadaniowych oraz czas $\boldsymbol{T}$ i koszty $\boldsymbol{K}$ wykonania robót $\boldsymbol{S}$. Zespoły $H^{r} \in \boldsymbol{H}$ projektowane są z dyspozycyjnych zasobów elementarnych $H^{r}=\left\{1,2, \ldots, h, \ldots, h^{r}\right\}$, które wydzielono do wykonania robót $\boldsymbol{S}$. Zbiory $\boldsymbol{T}$ i $\boldsymbol{K}$, które określają czas, w warunkach deterministycznych $t_{j, r} \in \boldsymbol{T}$ lub w warunkach stochastycznych $\widehat{T}_{j, r} \in \boldsymbol{T}$, i koszty, w warunkach deterministycznych $k_{r, j} \in \boldsymbol{K}$ lub w warunkach stochastycznych $\widehat{K}_{j, r} \in \boldsymbol{K}$, wykonania przez zespoły $H^{r} \in \boldsymbol{H}$ planowanych robót $u_{j} \in \boldsymbol{U} \subset \boldsymbol{G}$. Każdy zespół zadaniowy $H^{r}$, ze względu na skład i wyposażenie, może wykonywać tylko pewien zbiór robót $\boldsymbol{U}^{r} \in \boldsymbol{U},\left|\boldsymbol{U}^{r}\right| \geq 1$.

Modele technologii konstrukcji $S$ i technologii robót $\mathfrak{L}$ stanowią podstawę formułowania problemów przydziału zespołów zadaniowych $H^{r} \in \boldsymbol{H}$ do planowanych robót budowlanych $u_{j} \in \boldsymbol{U} \subset \boldsymbol{G}$. Zagadnienia przydziału zespołów zadaniowych sformułowano, jako zagadnienia jednokryterialne i dwukryterialne. Są to zadania programowania mieszane ciągło-binarne. Zmienne decyzyjne opisujące czas rozpoczęcia $v_{i}$ robót $u_{j} \in \boldsymbol{U},\left\langle y_{i}, u_{j}, y_{k}\right\rangle \in \boldsymbol{P}$ są zmiennymi ciągłymi. Natomiast zmienne przydziału $x_{j, r}, u_{j} \in \boldsymbol{U}$ i $H^{r} \in \boldsymbol{H}$, są zmiennymi binarnymi $x_{j, r}=$ 1 lub $x_{j, r}=0$. Każde sformułowanie zawiera kryterium lub kryteria wyboru rozwiązania, warunki ograniczające i warunki brzegowe. Kryteria zapewniają najlepszy w danych warunkach przydział zespołów zadaniowych. Warunki ograniczające zapewniają spełnienie wymagań kolejnościowych robót i zajętości zespołów zadaniowych.

Rozwiązanie jednokryterialne z kryterium „minimalizacja czasu robót” pozwala wyznaczyć optymalny przydział zespołów $\left(x_{j, r}=1\right.$ dla każdej roboty $\left.u_{j} \in \boldsymbol{U}\right)$, który zapewnia najkrótszy czas min $v_{w}$ wykonania robót $\boldsymbol{S}$. Mogą być wyznaczane najwcześniejsze terminy $v_{i}$ rozpoczęcia poszczególnych robót $u_{j} \in \boldsymbol{U}$ lub po pewnej modyfikacji sformułowania najpóźniejsze terminy $v_{i}$ rozpoczęcia poszczególnych robót $u_{j} \in \boldsymbol{U} \mathrm{z}$ zachowaniem najkrótszego $\min v_{w}$ czasu wykonania robót $\boldsymbol{S}$. 
Rozwiązanie jednokryterialne z kryterium „minimalizacja kosztów robót” pozwala wyznaczyć optymalny przydział zespołów $\left(x_{j, r}=1\right.$ dla każdej roboty $\left.u_{j} \in \boldsymbol{U}\right)$, który zapewnia najmniejsze koszty min $k$ wykonania robót $\boldsymbol{S}$. Wyznaczany jest również odpowiadający temu przydziałowi czas $v_{w}(k)$ ukończenia robót $\boldsymbol{S}$.

Rozwiązanie dwukryterialne z kryteriami „minimalizacja czasu robót” i „minimalizacja kosztów robót”, które rozpatrywane są jednocześnie, pozwala wyznaczyć kompromisowy przydział zespołów przydział zespołów zadaniowych $\left(x_{j, r}=1\right.$ dla każdej roboty $\left.u_{j} \in \boldsymbol{U}\right)$, który zapewnia możliwie krótki czas kompr $v_{w}=t$ i możliwie niskie koszty kompr $k_{w}=k$ wykonania robót $\boldsymbol{S}$.

Rozwiązanie wszystkich sformułowanych problemów przydziału dla deterministycznych lub stochastycznych warunków realizacji robót, można uzyskać na przykład za pomocą na przykład Excel’a z Solver'em. Metody przetestowano na przykładach robót budowlanych. Uzyskane wyniki badań potwierdzają słuszność przyjętych założeń i poprawność wyznaczanych rozwiązań.

Zastosowanie opracowanych metod przydziału zespołów zadaniowych w procesie analizy i projektowania realizacji robót jest teoretycznie możliwe bezpośrednio. Jednak biorąc pod uwagą wymagania znajomości tych metod i przyzwyczajenia potencjalnych użytkowników, zastosowanie ma szanse tylko po stworzeniu odpowiednich baz wiedzy, automatyzacji formułowania i rozwiązywania problemów przydziału oraz generowania wyników obliczeń. Jest to w pełni możliwe.

Received 15.04.2019

Revised 30.04.2019 